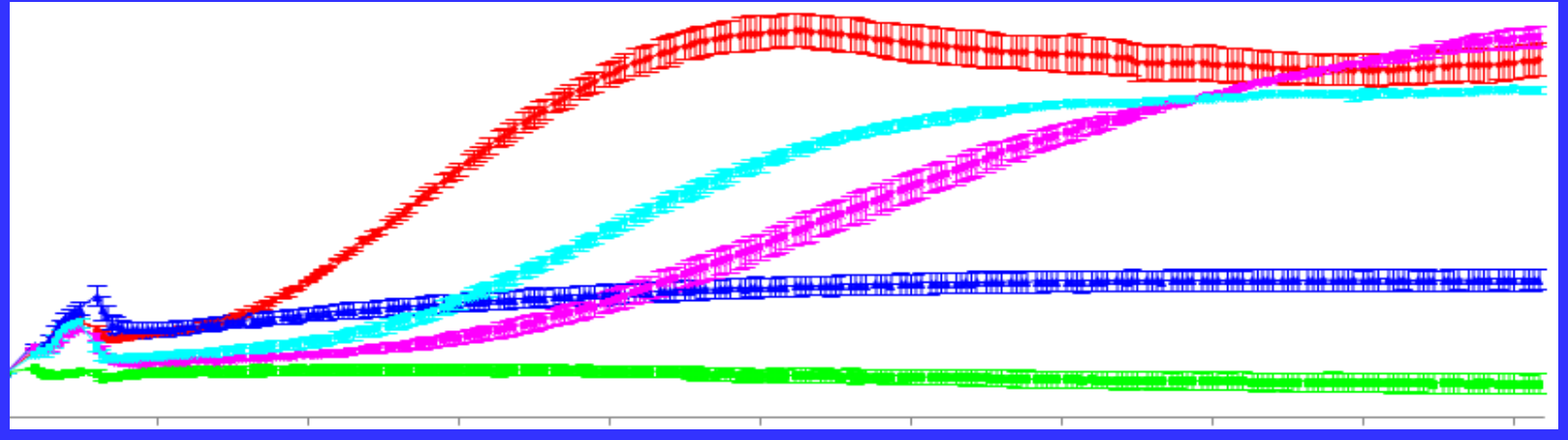

\title{
BJP
}

Bangladesh Journal of Pharmacology

Research Article

\section{HPLC analysis, anti-oxidant activity of Genista ferox and its anti- proliferative effect in HeLa cell line}




\section{HPLC analysis, anti-oxidant activity of Genista ferox and its anti- proliferative effect in HeLa cell line}

\section{Ilhem Bencherchar'1, Ibrahim Demirtas', Muhammed Altun'1, Fatih Gül1, Djamel Sarri², Fadila Benayache², Samir Benayache ${ }^{2}$ and Ratiba Mekkiou²}

${ }^{1}$ Department of Chemistry, Faculty of Science, Cankırı Karatekin University, Cankırı, Turkey; ${ }^{2}$ Valorization of Natural Resources, Bioactive Moleculesand Biological Analysis Unit, Department of Chemistry, University of Mentouri Constantine 1, Constantine 25000, Algeria.

\begin{tabular}{|c|c|}
\hline \multicolumn{2}{|l|}{ Article Info } \\
\hline Received: & 24 April 2017 \\
\hline Accepted: & 20 June 2017 \\
\hline Available Online: & 20 July 2017 \\
\hline \multicolumn{2}{|c|}{ DOI: 10.3329/bjp.v12i3.32310 } \\
\hline \multicolumn{2}{|c|}{$\begin{array}{l}\text { Cite this article: } \\
\text { Bencherchar I, Demirtas I, Altun M, } \\
\text { Gül F, Sarri D, Benayache F, Be- } \\
\text { nayache S, Mekkiou S. HPLC analy- } \\
\text { sis, anti-oxidant activity of Genista ferox } \\
\text { and its anti-proliferative effect in } \\
\text { HeLa cell line. Bangladesh J Pharma- } \\
\text { col. 2017; 12: 260-67. }\end{array}$} \\
\hline
\end{tabular}

\begin{abstract}
The prevention and treatment of the cancer using plants have attracted increasing interest. The present study was aimed to determine the phenolic compounds of Genista ferox using HPLC-TOF/MS and the anti-oxidant activity associated with anti-cancer activity against human cervical adenocarcinoma (HeLa) cell line. Total anti-oxidant capacities of different extracts of G. ferox were assessed by DPPH assay, and their total phenolic and flavonoids contents measured by Folin-Ciocalteu and aluminum trichloride assays. The amounts of total phenolic $(105.2 \pm 0.6-308.5 \pm 5.7 \mathrm{mg} / \mathrm{g})$ of extract measured as gallic acid equivalent and flavonoids $(8.1 \pm 0.1-124.0 \pm 0.7 \mathrm{mg} / \mathrm{g})$ of extract measured as quercetin equivalent varied from chloroform to $n$-butanol extract of the two parts of the plant (leaf and stem). The ethyl acetate extract of G. ferox exhibited the most powerful effect on the DPPH scavenging activity with $94 \%$ from the leaf and $93 \%$ from the stem, while the chloroform extract from the leaf exhibited the most effective anti-proliferative activity against HeLa cell lines.
\end{abstract}

\section{Introduction}

Plants used in ancient times as medicines to alleviate symptoms of various ailments (Saeed et al., 2012). In spite of the great progress in modern medicine in recent decades, but the herbal medicine still make an important contribution in the health care. Many medicinal and aromatic plants contain huge amounts of antioxidants such as polyphenols. These substances can have an important role in the absorption and neutralize free radicals, and the extinction of the shirt and triple oxygen or peroxide decomposing. Many of these phytochemicals have anti-oxidant capabilities so they contribute significantly to the fight against many human diseases and thus contribute to the reduction of mortality (Djeridane et al., 2006). Phenolic compounds such as flavonoids and phenolic acids have different biological effects, such as the effects of anti-atherosclerotic, anti-inflammatory and anti-cancer, as a result of the anti-oxidant activity (Krishnaiah et al., 2011).

The Fabaceae family contains approximately 700 genera, in Algeria there are about 53 genera and 337 species (Quezel and Santa, 1963). Genista genus has about 150 species in Europe and the Mediterranean region (RE, 1987). A literature survey shows that this genus is a good source of phenolic compounds, in particular isoflavonoids, which are known for their diverse biological activities. The recent studies on the species of the Genista genus showed pharmacological interest (Belle et al., 1995; Herrera et al., 1992).

In the present study, the qualitative and quantitative analysis, the identification and quantification of phenolic acids and flavonoids in chloroform, ethyl 
acetate, n-butanol and methanol extracts of Genista ferox using HPLC-TOF/MS were reported. All extracts were subjected to DPPH radical scavenging activity assay to evaluate the anti-oxidant activity as well as the estimation of anti-proliferative activity against HeLa cell lines.

\section{Materials and Methods}

\section{Plant material}

G. ferox was harvested from the region of El-kala (eastern Algeria) in May 2014 and identified by Dr. Djamel Sarri from the Department of Biology, M'Sila University. A voucher specimen had been deposited in the VARENBIOMOL research unit with the identification number 05/2014/FGF.

\section{Phytochemical screening}

Three organs of the plant material (fruit, leaf and stem) were separated and screened for different chemical constituents such as coumarins, saponins, quinone, flavonoids, alkaloids, anthocyanin and tannins using standard procedures (Ciulel, 1982; Linga Rao and Savithramma, 2011; Obasi Nnamdi et al., 2010).

\section{Extraction procedures}

The stems (1,075 g) of G. ferox was macerated at room temperature with a mixture of ethanol:water (70:30, v/ v) for 48 hours. The process was repeated thrice. After filtration, the filtrates were concentrated and finally dissolved in $430 \mathrm{~mL}$ of water which gave soluble and non-soluble parts in water. The aqueous phase (soluble part) was extracted successively with chloroform, ethyl acetate and n-butanol. The organic layers were concentrated in vacuum at room temperature to obtain the extracts. While, the non-soluble part was dissolved in the methanol to give the methanol extract.

A quantity of $700 \mathrm{~g}$ of leaves of G. ferox were macerate by the same manner as previously to obtain chloroform, ethyl acetate, $n$-butanol and methanol extracts.

The yields of different extracts of G. ferox were calculated using the formula:

Yield \% $(\mathrm{w} / \mathrm{w})=($ Amount $(\mathrm{g})$ of extract/Amount $(\mathrm{g})$ of plant) $\times 100$

\section{Quantitative analysis by HPLC-TOF/MS}

The quantification of flavonoids, phenolics and phenolic acids in all extracts was carried out using 1260 Infinity HPLC System (Agilent Technology) coupled with TOF (6210 Time of Flight) LC/MS detector and ZORBAX SB-C18 $(4.6 \times 100 \mathrm{~mm}, 3.5 \mu \mathrm{m})$ column. The mobile phase consisted of solvent mixtures (A) water (ultra-pure) with $0.1 \%$ formic acid and (B) acetonitrile, respectively. Flow rate and column temperature were $0.6 \mathrm{~mL} / \mathrm{min}$ and $35^{\circ} \mathrm{C}$, respectively. The solvent program was as follow: $0-1 \mathrm{~min} 10 \% \mathrm{~B} ; 1-20 \mathrm{~min} 50 \% \mathrm{~B}$;
$20-23 \min 80 \% \mathrm{~B} ; 23-30 \mathrm{~min} 10 \%$ B. The injection volume was $10 \mu \mathrm{L}$. Ionization mode of HPLC-TOF/MS instrument was negative mode and operated with a nitrogen gas at $325^{\circ} \mathrm{C}$, and gas flow of $10.0 \mathrm{~L} / \mathrm{min}$, nebulizer of $40 \mathrm{psi}$, capillary voltage of $3500 \mathrm{~V}$ and finally, fragmentor voltage of $175 \mathrm{~V}$. The crude extracts (200 ppm) were dissolved in methanol at room temperature. The particulates of the samples were removed using a PVDF $(0.45 \mu \mathrm{m})$ filter (Demirtas et al., 2013). The limits of detection were found to be between 25 and 2500 ppb using HPLC-TOF/MS.

\section{Determination of anti-oxidant activity}

Estimation of total phenolic content

The total phenolic content was determined by the method of Folin-Ciocalteau using gallic acid as a standard (Singleton and Rossi, 1965). $0.5 \mathrm{~mL}$ of gallic acid $(1 \mathrm{mg} / \mathrm{mL})$ of different concentrations was mixed with $1 \mathrm{~mL}$ of Folin-Ciocalteau reagent $\left(\begin{array}{ll}1 & \mathrm{~N}\end{array}\right)$ and allowed to stand at room temperature for $5 \mathrm{~min} .5 \mathrm{~mL}$ of $\mathrm{Na}_{2} \mathrm{CO}_{3}(20 \%)$ was added. The mixture was mixed and allowed to stand at room temperature in the dark for 2 hours. $0.5 \mathrm{~mL}$ of each extract $(1 \mathrm{mg} / \mathrm{mL})$ was prepared by the same manner as gallic acid. The absorbance was read at $765 \mathrm{~nm}$ and the result expressed as gallic acid equivalent (mg GAE/g of extract).

\section{Estimation of total flavonoid content}

The total flavonoid content was determined by the method of aluminum trichloride using quercetin as a standard (Ordonez et al., 2006). $1 \mathrm{~mL}$ of each extract (1 $\mathrm{mg} / \mathrm{mL}$ ) was mixed with $1 \mathrm{~mL}$ of $2 \%$ methanolic aluminum trichloride solution. The absorbance read at $420 \mathrm{~nm}$ after 1 hour. The absorption of quercetin standard solutions measured under the same conditions. The results are expressed as equivalent quercetin (mg QE/g of extract).

\section{DPPH radical scavenging}

Different dilutions $(1-100 \mu \mathrm{g} / \mathrm{mL})$ of extracts were prepared and a solution of DPPH was prepared by dissolving $2.4 \mathrm{mg}$ of DPPH in $100 \mathrm{~mL}$ methanol. Then, $50 \mu \mathrm{L}$ of each dilution was added to the test tubes containing $1.95 \mathrm{~mL}$ of the prepared DPPH solution. The negative control (sample) was prepared by adding 50 $\mu \mathrm{L}$ of methanol in $1.95 \mathrm{~mL}$ of the prepared $\mathrm{DPPH}$ solution. Ascorbic acid was used as standard. The mixture was allowed to stand in the dark for $30 \mathrm{~min}$. Absorbance was measured spectrophotometrically at $517 \mathrm{~nm}$. The scavenging activity was calculated using the equation.

$\mathrm{RSA}=\left[\left(\mathrm{A}_{\text {blank }}-\mathrm{A}_{\text {sample }}\right) / \mathrm{A}_{\text {blank }}\right] \times 100$

Where, $A_{\text {blank }}$ and $A_{\text {sample }}$ are the absorbance of the negative control (blank) and the sample, respectively

The $\mathrm{IC}_{50}$ value is defined as the concentration of antioxidant necessary to inhibit DPPH radical formation by 
$50 \%$. The synthetic anti-oxidant reagent, ascorbic acid was used as a positive control (Takao et al., 1994).

\section{Anti-proliferative activity}

Preparation of cell suspension

Human cervix carcinoma cells (HeLa) were grown at $37^{\circ} \mathrm{C}$ in a $\mathrm{CO}_{2}$ incubator $\left(5 \% \mathrm{CO}_{2}\right.$ and $95 \%$ humidified atmosphere). Dulbecco's Modified Eagle's MediumHigh Glucose (DMEM), Sigma, Germany) including $10 \%$ (v/v) fetal bovine serum (Sigma, Germany) and 2\% (v/v) streptomycin-penicillin (Sigma, Germany) was used as medium.

$10 \mathrm{~mL}$ trypsin-EDTA solution was added to culture flask to detach HeLa cells from bottom of the culture flask. The cells were incubated for $2-3 \mathrm{~min}$ at $37^{\circ} \mathrm{C}$ in a $\mathrm{CO}_{2}$ incubator. Thus, HeLa cells were removed from the surface. After detachment, the flask was removed from the incubator and $10 \mu \mathrm{L}$ DMEM (Dulbecco's Modified Eagle's Medium-High Glucose) was added into the flask to neutralize the medium. The cell suspension was transferred to $15 \mathrm{~mL}$ falcon tubes in equal amounts and centrifuged for $5 \mathrm{~min}$ at $600 \mathrm{rpm}$.

After removing the supernatant, $3 \mathrm{~mL}$ DMEM was added onto the cell pellets and resuspended carefully with a sterile pipette. The quantity of live cells of this cell suspension was measured automatically with cell counting device (CEDEX HiRes Innovatis, Roche). The cell counting device tagged the dead cells with trypan blue solution (Demirtas et al., 2013).

\section{Cell proliferation assay}

Anti-proliferative activity measurements were performed according to the method described elsewhere (Abay et al., 2015; Ökten et al., 2015). $50 \mu \mathrm{L}$ DMEM were added into each well of E-Plate 96. The plate was incubated in the steril cabinet for $15 \mathrm{~min}$ and in the $\mathrm{CO}_{2}$ incubator for $15 \mathrm{~min}$ to reach a thermal equilibrium. After this period, the plate was inserted to the xCELLigence RTCA device and a background impedance measurement was performed in the incubator (Step 1). This step continued 1 min. Then E-plate 96 was rejected from $x$ CElligence SP station and $100 \mu \mathrm{L}$ HeLa cells suspension $\left(2.5 \times 10^{4}\right.$ cells $\left./ 100 \mu \mathrm{L}\right)$ were added to each wells, except the last 3 wells. Only $100 \mu \mathrm{L}$ of medium (DMEM) was added to these 3 wells. Three wells were left blank to check if there would be an increase due to the culture medium.

The plate was left in the sterile cabinet at room temperature for $30 \mathrm{~min}$. After this stage, E-Plate 96 was inserted to $x$ CELLigence RTCA SP station in the $\mathrm{CO}_{2}$ incubator. A measurement was performed for $80 \mathrm{~min}$ (Step 2). In this step, the cancer cells were accommodated to medium and attached to the microelectrodes at the wells bottom. During this period, the cells conditions were measured every $10 \mathrm{~min}$.
The extracts were dissolved in sterile DMSO $(20 \mathrm{mg} /$ $\mathrm{mL}$ ). This sample solutions were diluted with DMEM in sterile tubes $(25 \mu \mathrm{L}$ sample/475 $\mu \mathrm{L}$ DMEM). Final DMSO concentration is below $1 \%$ in all tests.

After Step 2, E-Plate 96 was recaptured to sterile cabinet and the extract solutions were added into the wells in different concentrations $(10,20$ and $50 \mu \mathrm{L}$ equivalent to 50, 100 and $250 \mu \mathrm{g} / \mathrm{mL}$ concentrations, respectively). The final volumes of the wells were completed to 200 $\mu \mathrm{L}$ with DMEM. Each dose of the samples was repeated 3 times. No extract solution was added into the control and the medium wells. Then E-Plate 96 was inserted to xCELLigence RTCA device for the last step. The measurement was launched for 48 hours (Step 3). The cells conditions measured every $10 \mathrm{~min}$ during this step.

\section{Results}

\section{Yield of the extracts}

Table I represent the amount and yield of chloroform, ethyl acetate, $n$-butanol and methanol extracts of the two parts (leaf and stem) of G. ferox. Methanol and nbutanol extract showed high yield.

\begin{tabular}{|c|c|c|c|}
\hline \multicolumn{4}{|c|}{ Table I } \\
\hline \multicolumn{4}{|c|}{ Yields and amounts of extracts of G. ferox } \\
\hline & Extract & Amount (g) & Yield $\%(w / w)$ \\
\hline \multirow{3}{*}{ Leaves } & Chloroform & 00.7 & 0.001 \\
\hline & Ethyl acetate & 02.6 & 0.004 \\
\hline & Butanol & 13.0 & 0.019 \\
\hline \multirow{5}{*}{ Stems } & Methanol & 20.0 & 0.029 \\
\hline & Chloroform & 01.4 & 0.001 \\
\hline & Ethyl acetate & 04.7 & 0.004 \\
\hline & Butanol & 46.0 & 0.043 \\
\hline & Methanol & 49.0 & 0.046 \\
\hline
\end{tabular}

\section{Phytochemical screening}

The qualitative screening of G. ferox showed the presence of alkaloids, saponins, coumarins, tannins and flavonoids (Table II).

\section{Composition of aerial parts by HPLC-TOF/MS}

Different extracts of G. ferox were analyzed by HPLCTOF/MS method. The identification had been performed on the basis of their retention times and mass spectrometry by comparison with those of different standards. The results showed the presence of 44 compounds including 17 organic and phenolic acids (Table III), 27 flavonoids and phenolics (Table IV). Some of these compounds were present in very small quantity and it did not reach to the detection limits 
Table II

Phytochemicals of G. ferox

\begin{tabular}{|lccc|}
\hline Chemical groups & Fruit & Stem & Leaf \\
\hline Alkaloids & + & + & + \\
Saponins & + & + & + \\
Quinones & - & - & - \\
Coumarin & + & + & + \\
Tannins & + & + & + \\
Flavonoids & + & + & + \\
Anthocyanins & - & - & - \\
$\begin{array}{l}\text { Methanol extract } \\
\text { of stem }\end{array}$ & 49.0 & 0.1 & \\
\hline
\end{tabular}

(trace) so their concentrations did not appear. The main constituens of G. ferox were obtained as fumaric acid, diosmetin, apigenin, scutellarin and apigenin-7-glucoside.

The apigenin (contain the highest concentration in methanol extract) was the main component of other extracts except butanol. Fumaric acid was the major compound of $n$-butanol extracts. Ethyl acetate extract contained the highest concentration of apigenin, ferulic acid, vanillic acid, 4-hydroxybenzoic acid and scutellarin. In total, methanol and $n$-butanol extract of stem had highest concentrations in phenolic quantities.

\section{Determination of anti-oxidant activity}

Total polyphenol and flavonoid contents

The amount of total phenolic and flavonoid contents measured by Folin-Ciocalteu and aluminum trichloride methods, varied considerably between different extracts and ranged from $105.2 \pm 0.6$ to $308.5 \pm 5.7 \mathrm{mg} \mathrm{GAE} / \mathrm{g}$ for total phenolic and from $8.1 \pm 0.1$ to $124.0 \pm 0.7 \mathrm{mg}$ $\mathrm{QE} / \mathrm{g}$ for flavonoids (Table V). The highest concentrations of both total phenolic and flavonoids were found in ethyl acetate extract of both stem and leaf, respectively.

\section{DPPH radical scavenging}

The most effective DPPH radical scavenging was shown by both ethyl acetate extracts of leaf and stem compared to ascorbic acid used as a standard (Figure 1). Similarly, highest total phenolic content was found in ethyl acetate extract from the stem.

Ethyl acetate extract of both leaf and stem exhibited the highest anti-oxidant activity with an $\mathrm{IC}_{50}(14.2 \pm 0.02$

\section{Table III}

\section{Quantitative results of organic and phenolic acids in plant extracts (mg phenolic/ $\mathrm{kg}$ plant)}

\begin{tabular}{|c|c|c|c|c|c|c|c|c|c|}
\hline \multirow{2}{*}{$\begin{array}{l}\text { Organic and phenolic } \\
\text { acids }\end{array}$} & \multirow{2}{*}{$\begin{array}{c}\mathrm{RT} \\
(\mathrm{min})\end{array}$} & \multicolumn{4}{|c|}{ Leaf } & \multicolumn{4}{|c|}{ Stem } \\
\hline & & Butanol & $\begin{array}{l}\text { Chloro- } \\
\text { form }\end{array}$ & Methanol & $\begin{array}{l}\text { Ethyl } \\
\text { acetate }\end{array}$ & Butanol & $\begin{array}{l}\text { Chlo- } \\
\text { roform }\end{array}$ & Methanol & $\begin{array}{l}\text { Ethyl } \\
\text { acetate }\end{array}$ \\
\hline Gallic acid & 2.4 & Trace & Trace & nd & Trace & Trace & Trace & Trace & Trace \\
\hline Fumaric acid & 3.2 & 12.8 & Trace & 2.2 & Trace & 78.6 & Trace & Trace & 6.6 \\
\hline Gentisic acid & 4.5 & 1.6 & 0.0 & 0.8 & 0.7 & 11.3 & 0.1 & 3.5 & 2.5 \\
\hline Chlorogenic acid & 5.5 & 0.3 & 0.0 & nd & nd & nd & 0.1 & nd & nd \\
\hline 4-Hydroxybenzoic acid & 7.0 & 1.6 & 0.0 & 1.0 & 3.2 & 5.0 & 0.5 & 3.2 & 6.5 \\
\hline Protocatechuic acid & 7.1 & 2.1 & 0.1 & 2.3 & 0.3 & 11.0 & 0.2 & 7.2 & 0.7 \\
\hline Caffeic acid & 7.6 & Trace & Trace & Trace & 0.3 & 0.1 & Trace & Trace & 0.7 \\
\hline Vanillic acid & 7.9 & 3.1 & 0.5 & nd & 3.3 & 10.8 & 1.3 & nd & 7.8 \\
\hline Syringic acid & 8.1 & 1.4 & 0.1 & nd & 0.4 & 8.6 & 0.4 & nd & 1.0 \\
\hline 4-Hydroxybenzaldehyde & 9.4 & Trace & 0.1 & Trace & 0.1 & Trace & 1.0 & Trace & 0.0 \\
\hline Ellagic acid & 9.7 & Trace & Trace & Trace & Trace & Trace & Trace & nd & Trace \\
\hline Sinapic acid & 10.5 & Trace & Trace & Trace & Trace & Trace & 0.0 & Trace & 0.1 \\
\hline Ferulic acid & 10.6 & nd & 0.5 & nd & 5.2 & nd & 3.6 & nd & 8.9 \\
\hline$p$-Coumaric acid & 12.1 & Trace & Trace & Trace & Trace & Trace & trace & Trace & Trace \\
\hline $\begin{array}{l}\text { Protocatechuic acid ethyl } \\
\text { ester }\end{array}$ & 12.8 & Trace & Trace & Trace & Trace & Trace & 0.0 & Trace & Trace \\
\hline Salicylic acid & 13.1 & 1.7 & Trace & Trace & 0.9 & 5.5 & 0.5 & Trace & 2.7 \\
\hline Cinnamic acid & 15.2 & 0.5 & 0.6 & 0.9 & 0.1 & nd & 0.4 & 3.6 & nd \\
\hline \multicolumn{2}{|c|}{ Total organic and phenolic acids } & 25.1 & 1.9 & 7.2 & 14.5 & 130.9 & 8.1 & $\mathbf{1 7 . 5}$ & 37.5 \\
\hline
\end{tabular}


Table IV

Quantitative results of flavonoids and phenolics in plant extracts (mg phenolic/ kg plant)

\begin{tabular}{|c|c|c|c|c|c|c|c|c|c|}
\hline & & \multicolumn{4}{|c|}{ Leaf } & \multicolumn{4}{|c|}{ Stem } \\
\hline $\begin{array}{l}\text { Flavonoids and pheno- } \\
\text { lics }\end{array}$ & $\begin{array}{c}\text { RT } \\
(\mathrm{min})\end{array}$ & Butanol & $\begin{array}{l}\text { Chlo- } \\
\text { roform }\end{array}$ & Methanol & $\begin{array}{l}\text { Ethyl } \\
\text { acetate }\end{array}$ & Butanol & $\begin{array}{l}\text { Chloro- } \\
\text { form }\end{array}$ & Methanol & $\begin{array}{l}\text { Ethyl } \\
\text { acetate }\end{array}$ \\
\hline Catechin & 5.8 & 0.7 & nd & nd & nd & nd & 0.1 & nd & nd \\
\hline Rutin & 9.2 & 0.1 & Trace & 3.2 & 0.0 & 0.0 & Trace & 0.4 & 0.1 \\
\hline Polydatin & 9.6 & 2.9 & Trace & Trace & 0.9 & Trace & 0.2 & Trace & 0.9 \\
\hline Scutellarin & 9.7 & 0.3 & nd & Trace & 1.0 & 66.1 & Trace & 5.8 & 5.6 \\
\hline $\begin{array}{l}\text { Quercetin-3- } \beta \text {-D- } \\
\text { glucoside }\end{array}$ & 9.8 & Trace & nd & Trace & Trace & 14.0 & Trace & Trace & Trace \\
\hline Naringin & 10.5 & 0.6 & 0.0 & 0.2 & 0.1 & 6.2 & 0.2 & 0.5 & 0.3 \\
\hline Diosmin & 10.6 & 2.5 & 0.1 & nd & 0.5 & 13.6 & 0.4 & nd & 1.0 \\
\hline Taxifolin & 10.6 & nd & Trace & Trace & 0.3 & Trace & Trace & Trace & 1.0 \\
\hline Hesperidin & 10.8 & Trace & Trace & Trace & Trace & Trace & Trace & Trace & 0.0 \\
\hline Apigetrin & 10.9 & Trace & Trace & Trace & 0.7 & 16.1 & Trace & 1.1 & 3.3 \\
\hline Neohesperidin & 11.1 & Trace & Trace & Trace & Trace & Trace & Trace & Trace & Trace \\
\hline Myricetin & 11.9 & nd & Trace & Trace & Trace & Trace & 0.2 & Trace & Trace \\
\hline Baicalin & 12.0 & Trace & Trace & Trace & Trace & Trace & Trace & nd & Trace \\
\hline Fisetin & 12.1 & Trace & Trace & Trace & Trace & Trace & Trace & Trace & 0.8 \\
\hline Morin & 13.0 & 0.8 & 0.1 & 1.5 & 0.2 & 5.0 & 0.1 & 6.4 & 1.2 \\
\hline Resveratrol & 13.0 & Trace & Trace & nd & Trace & Trace & Trace & nd & Trace \\
\hline Quercetin & 14.0 & Trace & Trace & Trace & Trace & Trace & Trace & Trace & Trace \\
\hline Silibinin & 15.1 & Trace & Trace & nd & trace & nd & Trace & nd & Trace \\
\hline Apigenin & 15.6 & 0.0 & 1.7 & 59.6 & 11.8 & 62.5 & 18.9 & 343.1 & 43.8 \\
\hline Naringenin & 15.7 & Trace & Trace & Trace & 0.1 & Trace & 1.1 & Trace & 0.2 \\
\hline Kaempferol & 15.7 & nd & Trace & Trace & 0.1 & Trace & 0.2 & 2.5 & 0.7 \\
\hline Diosmetin & 16.1 & nd & 0.0 & 6.7 & 0.1 & nd & 0.2 & 51.7 & 0.9 \\
\hline Neochanin & 17.7 & nd & Trace & Trace & Trace & nd & Trace & Trace & Trace \\
\hline Eupatorin & 18.9 & nd & Trace & Trace & Trace & nd & Trace & Trace & nd \\
\hline Wogonin & 19.8 & Trace & Trace & Trace & Trace & nd & Trace & Trace & Trace \\
\hline Galangin & 20.5 & nd & Trace & Trace & Trace & Trace & Trace & Trace & Trace \\
\hline Biochanin A & & nd & nd & Trace & Trace & Trace & nd & trace & trace \\
\hline $\begin{array}{l}\text { Total flavonoids and } \\
\text { phenolics }\end{array}$ & & 7.9 & 1.9 & 71.2 & 15.8 & 183.5 & 21.6 & 411.5 & 59.8 \\
\hline
\end{tabular}

\section{Table V}

\section{Total phenolic and flavonoid values of G. ferox}

\begin{tabular}{|llrr|}
\hline Extract & & \multicolumn{1}{c}{$\begin{array}{c}\text { Total phenolic } \\
\text { content } \\
\text { (mg GAE/g) }\end{array}$} & \multicolumn{1}{c|}{$\begin{array}{c}\text { Flavonoid } \\
\text { content } \\
\text { (mg QE/g) }\end{array}$} \\
\hline Chloroform & Leaf & $172.1 \pm 0.5$ & $48.5 \pm 0.2$ \\
& Stem & $190.6 \pm 5.9$ & $30.7 \pm 0.4$ \\
Ethyl acetate & Leaf & $182.9 \pm 0.8$ & $124.0 \pm 0.7$ \\
& Stem & $308.5 \pm 5.7$ & $92.2 \pm 0.1$ \\
$n$-Butanol & Leaf & $105.2 \pm 0.6$ & $8.1 \pm 0.1$ \\
& Stem & $144.3 \pm 0.02$ & $11.6 \pm 0.1$ \\
\hline
\end{tabular}

and $14.9 \pm 0.1) \mu \mathrm{g} / \mathrm{mL}$, respectively. On the other hand, $n$-butanol extract exhibited the lowest anti-oxidant activity with an $\mathrm{IC}_{50}$ of $55.5 \pm 0.2$ and $52.5 \pm 1.0 \mu \mathrm{g} / \mathrm{mL}$, respectively.

\section{Anti-proliferative activity}

Figure 2 shows the results of real-time monitoring (xCELLigence RTCA SP, ACEABIO) of the proliferation of HeLa cells treated with different solvent extracts obtained from G. ferox. These anti-proliferative activity results are different due to the phytochemical composition of several solvent extracts of G. ferox. The cell index results provide a clear evidence that the antiproliferative activities of all solvent extracts were 


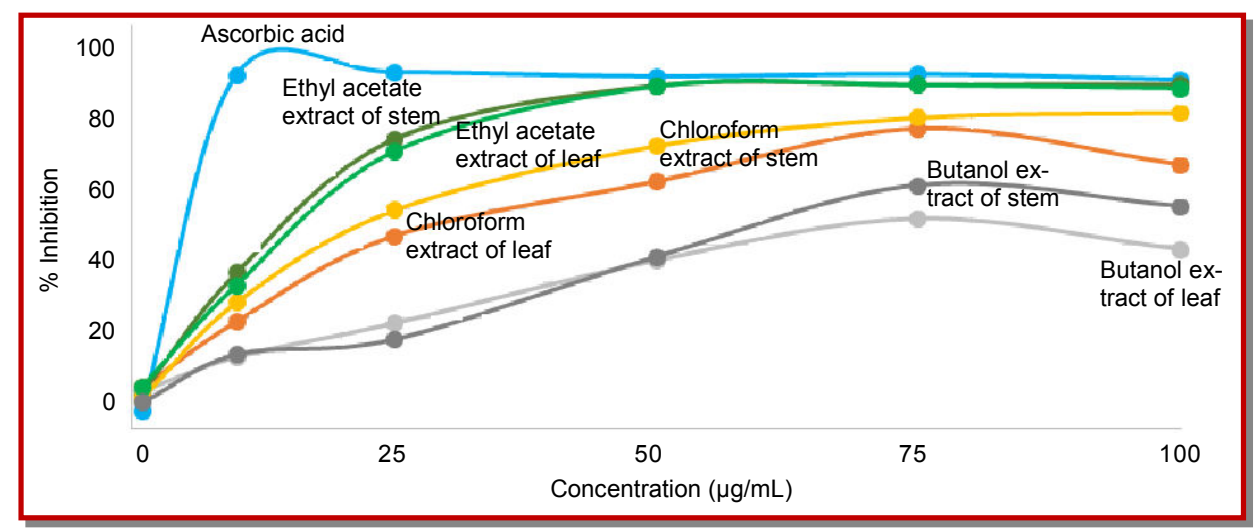

Figure 1: DPPH scavenging activity of different extracts of Genista ferox and ascorbic acid as a standard

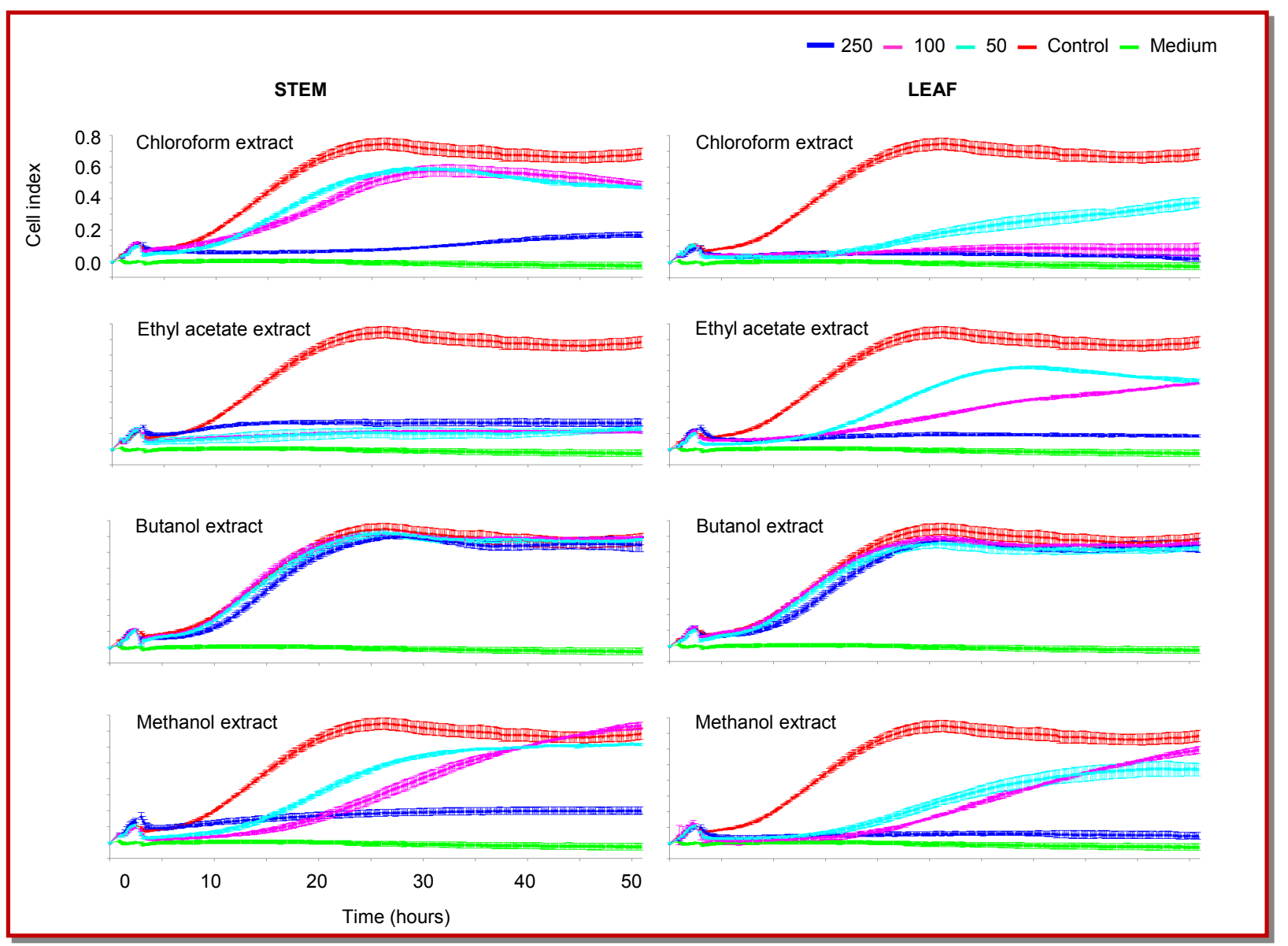

Figure 2: Proliferation assays of stem (left column) and leaf (right column) extracts at various concentrations ( $\mu \mathrm{g} / \mathrm{mL}$ )

similar, except for $n$-butanol extracts, which are inactive. HeLa cells were inhibited by chloroform, ethyl acetate and methanol extracts at high concentration (250 $\mu \mathrm{g} / \mathrm{mL})$, while low activities were obtained at 100 and $50 \mu \mathrm{g} / \mathrm{mL}$ concentrations of these extracts in a timedependent manner. Although the anti-proliferative activity of ethyl acetate extract of stem and chloroform extract of leaf increased at concentrations of 100 and 250 $\mu \mathrm{g} / \mathrm{mL}$. Higher activities were obtained only at $250 \mu \mathrm{g} /$ $\mathrm{mL}$ for chloroform (stem), methanol (stem), ethyl acetate (leaf) and methanol (leaf) extracts. n-Butanol extracts of stem and leaf showed no activity at any concentrations. Apigenin is the major component for methanol (stem), n-butanol (stem) and ethyl acetate (leaf) extracts (Table IV). Diosmetin was the major component for methanol extracts. According to the quantitative results, $n$-butanol extract of stem had high phenolic standards. It had no anti-oxidant and antiproliferative activities. In addition, although ethyl acetate extract of stem had low phenolic standards. It 
had highest anti-oxidant and anti-proliferative activities.

\section{Discussion}

The phytochemical studies of G. ferox revealed the presence of phenolic compounds synthesized in the secondary metabolism of the plant are known by their active substance; for that reason the anti-oxidant and anti-proliferative activities were studied for extracts of G. ferox. The results confirmed that chloroform, ethyl acetate, $n$-butanol and methanol extracts of leaf and stem did not demonstrated the similar activities. Ethyl acetate extracts exhibited the highest anti-oxidant activities whereas $n$-butanol extracts exhibited the lowest anti-oxidant activities.

The strong positive correlations between DPPH radical scavenging activity and total phenolic and flavonoid contents were obtained. The results of ethyl acetate extracts showed the highest anti-oxidant activities. The anti-oxidant activity may be due to one or more of these compounds and there are several studies in recent years about the anti-oxidant activities of phenolic acids (Fukumoto and Mazza, 2000; Villa no et al., 2005). EAS have low phenolic standards; it has highest anti-oxidant and anti-proliferative activities. As the reason for this, it may be due to the unknown compounds.

The coordination between anti-cancer activity and phenolic compounds seems to depend on the chemical properties of the natural products and the cancer cells. Many secondary metabolites as polyphenols and flavonoids have been reported to retain proliferation and angiogenesis of cancer cells in vitro. The anticarcinogenic activity of G. ferox may be due to synergistic effects of these bioactive compounds.

\section{Conclusion}

G. ferox possesses significant anti-oxidant and antiproliferative activities in some solvent extracts, establishing the ethnopharmacological basis for the use of this plant in traditional medicine. The cell index results of G. ferox extracts provide clear evidence that the antiproliferative activities of all solvent extracts are higher, except for $n$-butanol extracts of leaf and stem against HeLa cells.

\section{Acknowledgement}

This study was supported by grants the Algerian Ministry of Higher Education, Turkish State Planning Organization (DPT2010K120720) and Çankırı Karatekin University.

\section{Conflict of Interest}

All authors have completed the ICMJE uniform disclosure form and declare no support from any organization for the submitted work.

\section{References}

Abay G, Altun M, Koldas S, Tufekci AR, Demirtas I. Determination of anti-proliferative activities of volatile contents and HPLC profiles of dicranumscoparium (Dicranaceae, Bryophyta). Comb Chem High T Scr. 2015; 18: 453-63.

Belle R, Barrachina MD, Martinez-Cuesta MA, Esplugues J. Pharmacological screening of the methanol and dichloromethanol extracts of Genista patens. Phytotherapy Res. 1995; 9: 495-99.

Ciulel I. Methodology for analysis of vegetable drugs. Romania, 1982.

Demirtas I, Gecibesler IH, Yaglioglu AS. Anti-proliferative activities of isolated flavone glycosides and fatty acids from stachysbyzantina. Phytochem Lett. 2013; 6: 209-14.

Djeridane A, Yousfi M, Nadjemi B, Boutassouna D, Stocker P, Vidal N. Anti-oxidant activity of some algerian medicinal plants extracts containing phenolic compounds. Food Chem. 2006; 97: 654-60.

Dzoyem JP, McGaw, LJ, Eloff1 JN. In vitro antibacterial, antioxidant and cytotoxic activity of acetone leaf extracts of nine under-investigated Fabaceae tree species leads to potentially useful extracts in animal health and productivity. BMC Complement Altern Med. 2014.

Erbil N, Duzguner V, Durmuskahya C, Alan Y. Antimicrobial and anti-oxidant effects of some Turkish fodder plants belongs to Fabaceae family (viciavillosa, trifoliumochroleucum and onobrychisaltissima). Orient J Chem. 2015; 31: 53-58.

Fukumoto LR, Mazza G. Assessing anti-oxidant and prooxidant activities of phenolic compounds. J Agric Food Chem. 2000; 48; 3597-604.

Herrera MD, Marhuenda E, Gibson A. Effects of genistein, an isoflavone isolated from genista trident ata, on isolated guinea-pig ileum and guinea-pig heal myenteric plexus. Planta Med. 1992.

Krishnaiah D, Sarbatly R, Nithyanandam R. A review of the anti-oxidant potential of medicinal plant species. Food and Bioproducts Processing, 2011; 217-33.

LingaRao M, Savithramma N. Phytochemical studies of svensoniahyderobadensis (Walp.) Mold: A rare medicinal plant. Pharm Lett. 2011; 3: 51-55.

Obasi Nnamdi L, Egbuonu A, Ukoha P, Ejikeme P. Comparative phytochemical and antimicrobial screening of some solvent extracts of samaneasaman (Fabaceae or mimosaceae) pods. Afr J Pure Appl Chem. 2010; 4: 206-12.

Ordonez AAL, Gomez JD, Vattuone MA, Isla MI. Anti-oxidant activities of sechiumedule (Jacq.) Swartz extracts. Food 
Chem. 2006; 97: 452-58.

Okten S, Erenler R, Köprülü TK, Tekin Ş. In vitro antiproliferative/cytotoxic activity of 2,3 -biindole against various cancer cell lines. Turk J Biol. 2015; 39: 15-22.

Quezel PS, Santa S. New flora of Algeria and the southern desert regions. Vol 2. Paris, Tela Botanical Association, 1963 (In French).

Re RM. Flore De Lafraque Du Nord.1987; 16.

Saeed N, Khan MR, Shabbir M. Anti-oxidant activity, total phenolic and total flavonoid contents of whole plant extracts Torilisleptophylla L. BMC Complement Altern Med. 2012;
12: 221.

Singleton V, Rossi JA. Colorimetry of total phenolics with phosphomolybdic-phosphotungstic acid reagents. Am J Enol Viticult. 1965; 16: 144-58.

Takao T, Kitatani F, Watanabe N, Yagi A, Sakata K. A simple screening method for anti-oxidants and isolation of several anti-oxidants produced by marine-bacteria from fish and shellfish. Biosci Biotech Bioch. 1994; 58: 1780-83.

Villa no De, Fern'andez-Pach'on MS, Troncoso AM, Garc'iaParrilla MC. Comparison of anti-oxidant activity of wine phenolic compounds and metabolites in vitro. Anal Chim Acta. 2005; 538: 391-98. 


\section{Your feedback about this paper}

1. Number of times you have read this paper 0

2. Quality of paper Click

3. Your comments

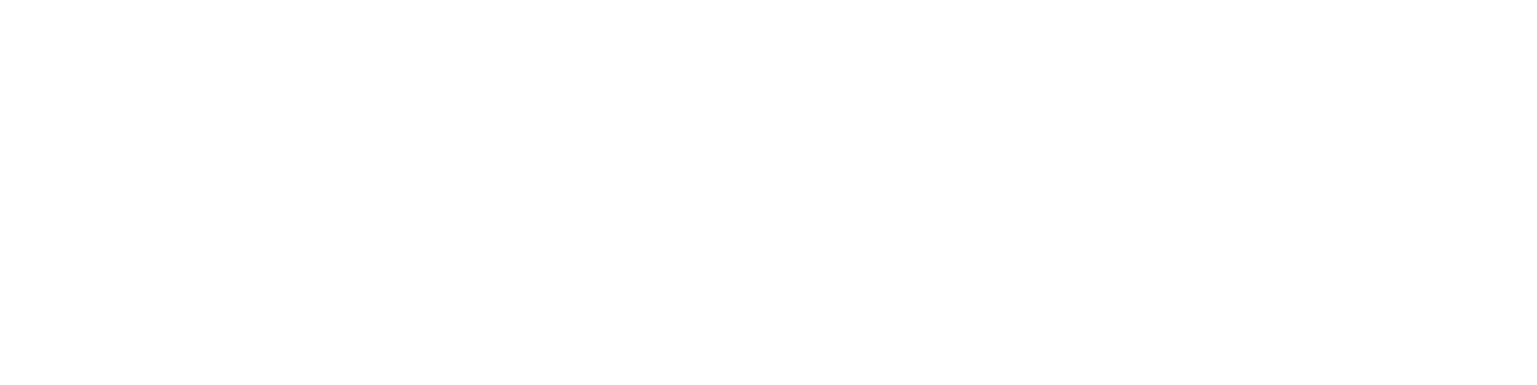

